\title{
Arte autoetnográfica
}

Heidrun Krieger Olinto, DUC-RJ

Um dos artigos do belo manifesto Artelatina apresenta-se como vigoroso convite à liberação de sensibilidades, de "fantasias e ansiedades", uma vez que, segundo o seu autor Silviano Santiago, o "blablablá teórico não é o bastante" para entendê-la. ${ }^{1}$ Em que pesem as diferenças entre a prática artística e o ofício de produção de conhecimento, parece-me oportuno esboçar o nexo entre a demanda expressa no manifesto e a intenção do projeto de Daniela Versiani, que ensaia com saber e sabor a difícil travessia entre gestos subjetivos, atos empíricos e opções de sua descrição e teorização. Sem a tentação usual de reduzir a complexidade de seus objetos de análise pelos rituais da generalização.

Neste sentido, Autoetnografias: conceitos alternativos em construção (Daniela Beccaccia VERSIANI, Rio de Janeiro: 7Letras, 2005) oferece uma leitura fascinante da geografia intelectual contemporânea dos campos das ciências humanas e sociais, avessos ao fechamento de suas fronteiras disciplinares. Centradas sobre possíveis articulações entre estudos de literatura, de cultura e de antropologia, as indagações tematizam intercâmbios e cruzamentos alheios à hifenização comum que alinha de modo contíguo e distinto os seguintes termos: auto-etno-grafia. A revisão crítica de para- digmas clássicos, legitimados pela marca da discriminação que respeita os limites dos territórios particulares da consciência de si, da consciência do outro e da forma de sua escrita, culmina assim no questionamento destes pela fórmula compósita radical da autora: autoetnografia. Nesta tradução o mito da integridade do self é afrontado pela cacofonia de múltiplas vozes sem síntese; a descrição do outro como objeto é substituído pelo diálogo interminável e tenso entre subjetividades distintas e a escrita, de modo geral, vista como reprodução transparente de realidades exteriores, é questionada a favor de seu estatuto performático de evento.

O pensamento construtivista, não-dualista, permeia todos os pressupostos epistemológicos que dão contorno às indagações, apontando para o olhar participativo do analista, ele mesmo inserido em contextos concretos circunscritos em sua dimensão temporal e espacial. Neste âmbito, o livro de Versiani inscreve-se na atmosfera filosófica batizada como "despertar epistemológico", que inspirou grande parte das revoluções paradigmáticas ocorridas nas últimas décadas. O seu chamado método autoetnográfico abre horizontes para uma atitude auto-reflexiva explícita da autora com respeito aos pressupostos privile- 
giados por ela que orientam o seu ângulo de visão e sinalizam a sua sintonia com a investigação científica mais avançada no espaço disciplinar da antropologia e dos estudos de literatura. Nas duas esferas - e não apenas nelas - passou a ser senso comum que os objetos não possuem sentido substancial inerente que se oferece ao olhar sem mediação. Do etnógrafo o princípio da observação participativa demanda, neste sentido, a conscientização do próprio lugar ocupado no complexo campo de contingências e possibilidades que articulam a sua vida privada com pertencimentos coletivos e com inserções institucionais e políticas, responsáveis pelo desenho misterioso construído por seu olhar.

De forma semelhante nos estudos de literatura - que deslocaram o seu compromisso tradicional com a interpretação do texto literário para o vasto espaço da comunicação literária vinculada com processos de produção, mediação, recepção e análise crítica - desponta a figura auto-reflexiva do observador de segunda ordem como antídoto para a ingenuidade epistemológica que entende literatura como espelho da realidade. E na descrição autoetnográfica ela emerge como barreira contra a transformação do outro em objeto.

O mérito e a originalidade do livro podem ser creditados, em parte, à dupla formação de Versiani - antropóloga e teórica da literatura - que lhe permitiu cimentar com segurança e competência perigosas travessias disciplinares e enxergar o valor das condições subjetivas do conhecimento, não como relativismo cultural, mas como abertura para novos questionamentos éticos no próprio fazer científico.

Os desafios deste empreendimento complexo são enfrentados com a sensibilidade da professora de literatura e cultura que intercambia o seu saber com aqueles que se iniciam na sua construção.Mas isto não é o bastante, como diria Silviano Santiago. O prazer da leitura deste belo livro se deve, também, ao encontro com a escritora de ficção: Daniela Gianna Claudia Beccaccia Versiani.

1 SANTIAGO, Silviano. "Artelatina (Manifesto)". In: Reinaldo Marques e Lúcia Helena Vilela (orgs.). Valores: Arte, mercado, política. Belo Horizonte: Editora UFMG/Abralic, 2002, p. 57-60. 